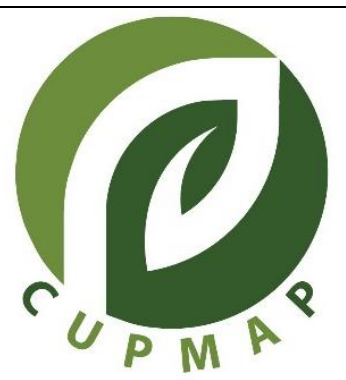

\title{
Taxonomic Investigation of Medicinal and Aromatic Plants with Natural Growing Characteristics in Kastamonu (Hanönü) Region
}

\author{
${\text { Murat } \text { ÖZOCAK }^{1}}^{(\text {(D) }}$, Erkan ÜNALAN ${ }^{2}$ (D) \\ ${ }^{1}$ Ministry of Agricultural and Forestry, District Agriculture and Forestry Directorate of Kastamonu- Hanönü Postal \\ code: 37100 , Kastamonu, Turkey \\ *Corresponding author: murat.ozocak@outlook.com \\ ${ }^{2}$ Mınıstry of Agrıcultural and Forestry, District Agrıculture and Forestry Directorate of Kastamonu- Hanönü, Postal \\ code: 37100 , Kastamonu, Turkey \\ E-mail: mai turk37@hotmail.com
}

https://doi.org/10.38093/cupmap.765409

Received : 19/05/2020 Accepted : 19/11/2020

\begin{abstract}
Our country has a wide flora in terms of growing and general distribution of medicinal and aromatic plants. The wide spread of these plants and the work in this field are increasing day by day. Based on this situation, a taxonomic study of 33 medical and aromatic plants showing natural distribution and playing a big role in terms of human health has been carried out in Hanönü district of Kastamonu region, which has a botanical wide flora. Images of all the identified species were taken in the growing region. Along with the pictures of the plants detected, the names of local usage and scientific Latin names and the places where they grow in the region are briefly explained. Recommendations were made to raise awareness of the consumption of the identified species, and to prevent unnecessary consumption and extinction. Beside, it is recommended to increase the scientific research on the subjects such as cultivation, drying parameters and storage of medicinal and aromatic plants starting from the Kastamonu region.
\end{abstract}

Key Words: Aromatic plants, Botanical, Kastamonu, Medicinal Plants, Flora, Taxonomical Investigation

(C) CUPMAP. All rights reserved.

\section{Introduction}

Humanity has been benefiting from plants for a therapeutic purpose since its existence. In the current situation, although the use continues, the majority of researches on medicinal and aromatic plants show the prevalence of these plants. Our country has a rich plant resource in terms of climate conditions. With the latest diagnoses, it has been determined that more than 11.000 plant taxa grow in Turkey, and approximately 3035 of these taxa are endemic (endemism rate 31.12\%)(Gürbüz, 1999; Güner, 2012; Öztürk et al.)

Medicinal and aromatic plants used in a wide range. Although it does not contain a wide range of areas at present, you can choose to group the plants according to their families beneficial parts and contentbased active ingredients (Ceylan, 1995; Altay et al., 2015a,b). Due to the ecological richness of our country, a large number of plants that can be used for medicinal and 
aromatic purposes can be grown. (Karahan et al., 2020). Some plants are collected from nature and some are provided by agricultural production. laurel plants collected from nature, mahleb, lime blossom, sage, rosemary, juniper and licorice are examples shells. Those cultivated can be cumin, anise, thyme, fenugreek, fennel, mint and coriander (Kızll et al., 2010).

In a study conducted on medicinal and aromatic plants in Kastamonu region, the awareness of naturally growing medicinal and aromatic plants in Tașköprü district was investigated by the local people. In the study, questions were asked to the people of the region about 26 medicinal and aromatic plants. As a result of the research, it was determined that most garlic, blackberry, nettle, rosehip, wild pear, linden and thyme plants are known and used in the region. The least known plants were found to be ragweed, yarrow and laden (Öztürk et. al. 2017)

In the study conducted by Yaman (2001) in which medicinal and aromatic plants that grow naturally in Kastamonu province and generate income for the region were evaluated, some plants that stand out economically were determined. According to the research, St. John's Wort, rosehip, salep, lamb belly mushroom, yellow mushroom, bear mushroom came to the fore in terms of income and natural growing conditions.

Within the scope of the research, the taxonomic examination of the medicinal and aromatic plants, which have become a very important sector in the world, under the conditions of Kastamonu (Hanönü), which has rich ecological features, is aimed. For this purpose, field studies were carried out in the region and all of the found species were recorded. The locations of each plant determined in the region are also recorded, and a study that will shed light on the medicinal and aromatic plants that are becoming more and more important every day.

\section{Material and Method}

The material of the research forms medicinal and aromatic plant species grow naturally in Hanönü of Turkey's Kastamonu province. Kastamonu Turkey's Black Sea Region in the northern part of our country is indigenous. Sinop, Çorum, Çankırı, Karabük and Bartın are the provinces and they have a coast to the Black Sea in the north.

The center of the city is in the city of Kastamonu with the same name. $74,6 \%$ of the face measurement of Kastamonu province consists of mountainous and woodland, 21,6\% plateau and 3,8\% plains. In general, there are large areas suitable for agriculture. Small plains, which take an important place in the valleys, are treated as important areas where such operations are carried out. The district of Alan Hanönü, which is a branch of Kizılırmak, is located in Taşköprü district, Sinop province Boyabat district, which is connected to many towns until 1988.

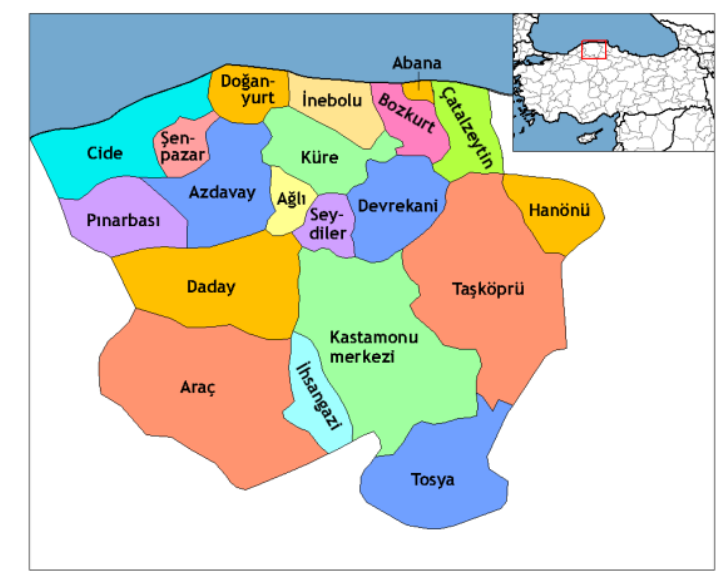

Figure 1. Kastamonu (Hanönü) Region (Anonymus, 2020).

For the method to be followed in the research, a literature review related to flora studies related to Kastamonu (Hanönü) has been made, and no comprehensive study 
has been found regarding the region, especially in terms of medicinal and aromatic plants. In this respect, the way to be followed as a research method has been completely formed by land formation. During the studies conducted in the district center and villages, continuous meetings were held with the people of the region, and subjects such as the local user names of the medicinal and aromatic plants grown in the region from the past to the present day and the regions where they were grown and recorded.

\section{Results and Discussıon}

Land works in the region were carried out until July 2020, throughout 2019. 33 medical and aromatic plant taxa were determined in the region, which was carried out by the Agricultural Engineer Murat ÖZOCAK and Agricultural Engineer Erkan ÜNALAN. The scientific names and families of the taxa in accordance with the systematic index obtained as a result of the local names of all the plants found, for what purpose and which regions are used, as well as the researches performed by Davis (1965; 1967; 1970; 1972; 1975; 1978; 1982; 1984; 1985). It indicated.

The families and the names of the medicinal and aromatic plants in the field studies conducted in the scope of the research, their location in the region, their local names from the past and their Scientific names are briefly explained.

As a result of the field studies in the region, a total of 33 plants that can be used for medicinal and aromatic purposes were determined. All information about the detected plants are presented in Table.1 and tried to be explained under subtitles.

\section{Anatolian Sage}

(Salvia anatolica Hamzaoglu \& A.Duran)

Salvia anatolica Hamzaoglu \& A.Duran , which is known as Anatolian sage and belongs to Lamiaceae family, is grown in many places in the region. It was discovered in the Yozlu area of the Vakıf District in the research area. $623 \mathrm{~m}$ from the sea Anatolian Sage, located at a height of $79 \mathrm{~km}$ from the city center.

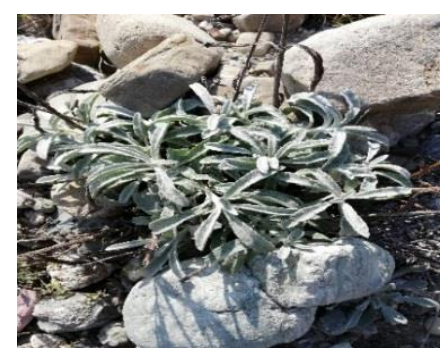

(Murat Özocak/Erkan Ünalan- 07.06.2020)

Figure 2. Salvia anatolica Hamzaoglu \& A.Duran

\section{Basil}

(Ocimum basilicum var. album (L.) Benth.) Belonging to the Lamiaceae family, basil is also known as basil in the region. It was discovered in the Karabük Neighborhood of Așağı Çakırçay Village in the research area. location $914 \mathrm{~m}$ from the sea. and $81 \mathrm{~km}$ away from the city center.

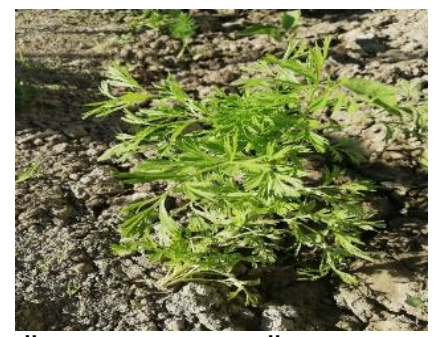

(Murat Özocak/Erkan Ünalan- 12.06.2020)

Figure 3. Ocimum basilicum var. album (L.) Benth. 
Table.1. Medicinal and aromatic plants detected in Kastamonu (Hanönü) Region

\begin{tabular}{|c|c|c|c|c|c|}
\hline Plant name & Famıly & District / Village & $\begin{array}{l}\text { Altitude } \\
\text { (m.) }\end{array}$ & $\begin{array}{c}\text { Location } \\
\text { (Distance to the } \\
\text { city center }(\mathrm{km}) \\
\end{array}$ & $\begin{array}{l}\text { Geography } \\
\text { Coordinates }\end{array}$ \\
\hline $\begin{array}{l}\text { Anatolian Sage (Salvia anatolica Hamzaoglu \& } \\
\text { A.Duran) }\end{array}$ & Lamiaceae & $\begin{array}{l}\text { Vakıf/Yozlu } \\
\text { located }\end{array}$ & 623 & 79 & $\begin{array}{c}34^{\circ}-26^{\prime}-14,86^{\prime \prime} / 41^{\circ}- \\
37^{\prime}-40,42^{\prime \prime}\end{array}$ \\
\hline $\begin{array}{l}\text { Basil } \\
\text { (Ocimum basilicum var. album (L.) Benth.) }\end{array}$ & Lamiaceae & $\begin{array}{l}\text { Așağıçakırçay/ } \\
\text { Karabük located }\end{array}$ & 914 & 81 & $\begin{array}{c}34^{\circ}-33^{\prime}-39,09^{\prime \prime} / 41^{\circ}- \\
38^{\prime}-26,65^{\prime \prime}\end{array}$ \\
\hline $\begin{array}{l}\text { Belladonna } \\
\text { (Atropa belladonna L.) }\end{array}$ & Solanaceae & $\begin{array}{l}\text { Hanönü/Donaşar } \\
\text { located }\end{array}$ & 472 & 72 & $\begin{array}{c}34^{\circ}-27^{\prime}-33,92^{\prime \prime} / 41^{\circ}- \\
37^{\prime}-25,11^{\prime \prime}\end{array}$ \\
\hline $\begin{array}{l}\text { Bitter melon } \\
\text { (Ecballium elaterium (L.) A.Rich) }\end{array}$ & Cucurbitaceae & Yenice located & 438 & 85 & $\begin{array}{c}34^{\circ}-32^{\prime}-59,14^{\prime \prime} / 41^{\circ}- \\
36^{\prime}-56,37^{\prime \prime}\end{array}$ \\
\hline $\begin{array}{l}\text { Blackthorn } \\
\text { (Paliurus spina-christi Mill.) }\end{array}$ & Rhamnaceae & $\begin{array}{l}\text { Kavak/Sinözü } \\
\text { located }\end{array}$ & 929 & 81 & $\begin{array}{l}34^{\circ}-28^{\prime}-3,17^{\prime \prime} / 41^{\circ}-39^{\prime}- \\
29,07^{\prime \prime}\end{array}$ \\
\hline $\begin{array}{l}\text { Burdock } \\
\text { (Arctium lappa subsp. platylepis (Boiss. \& } \\
\text { Balansa) Arènes) }\end{array}$ & Compositae & $\begin{array}{l}\text { Bölükyazı/Çay } \\
\text { located }\end{array}$ & 972 & 61 & $\begin{array}{c}34^{\circ}-25^{\prime}-48,34 " / 41^{\circ}-39^{\prime}- \\
25,64^{\prime \prime}\end{array}$ \\
\hline $\begin{array}{l}\text { Buttercup } \\
\text { (Ranunculus ficaria var. bulbifera Albert) }\end{array}$ & Ranunculaceae & $\begin{array}{l}\text { Sirke/Düzen } \\
\text { located }\end{array}$ & 546 & 57 & $\begin{array}{c}34^{\circ}-22^{\prime}-20,30^{\prime \prime} / 41^{\circ}- \\
37^{\prime}-48,69^{\prime \prime}\end{array}$ \\
\hline $\begin{array}{l}\text { Caper } \\
\text { (Capparis spinosa subsp. aegyptia (Lam.) Kit } \\
\text { Tan \& Runemark) }\end{array}$ & Capparaceae & $\begin{array}{l}\text { Küreçayı/ Kıraç } \\
\text { located }\end{array}$ & 605 & 80 & $\begin{array}{c}34^{\circ}-24^{\prime}-21,08^{\prime \prime} / 41^{\circ}- \\
38^{\prime}-16,73^{\prime \prime}\end{array}$ \\
\hline Charlock (Sinapis arvensis L.) & Brassicaceae & $\begin{array}{l}\text { Bölükyazı/ Yozlu } \\
\text { located }\end{array}$ & 987 & 65 & $\begin{array}{c}34^{\circ}-25^{\prime}-54,49^{\prime \prime} / 41^{\circ}- \\
38^{\prime}-3,10^{\prime \prime}\end{array}$ \\
\hline $\begin{array}{l}\text { Dandelion } \\
\text { (Taraxacum officinale (L.) Weber ex } \\
\text { F.H.Wigg.) }\end{array}$ & Asteraceae & $\begin{array}{l}\text { Gökçeağaç/Karaa } \\
\text { gaaçaltı }\end{array}$ & 448 & 76 & $\begin{array}{c}34^{\circ}-30^{\prime}-27,29^{\prime \prime} / 41^{\circ}- \\
37^{\prime}-48,53^{\prime \prime}\end{array}$ \\
\hline Dead nettle (Urtica dioica L.) & Urticaceae & $\begin{array}{c}\text { Hocavakıf/Karaol } \\
\text { uk located }\end{array}$ & 643 & 83 & $\begin{array}{c}34^{\circ}-23^{\prime}-52,80^{\prime \prime} / 41^{\circ}- \\
40^{\prime}-17,02^{\prime \prime}\end{array}$ \\
\hline $\begin{array}{l}\text { Elderberry } \\
\text { (Sambucus adnata Wall. ex DC.) }\end{array}$ & Adoxaceae & $\begin{array}{l}\text { Hanönü/Bürnük } \\
\text { located }\end{array}$ & 423 & 79 & $\begin{array}{c}34^{\circ}-27^{\prime}-9,22^{\prime \prime} / 41^{\circ}-42^{\prime}- \\
45,23^{\prime \prime}\end{array}$ \\
\hline False hemp (Cannabina laevis Moench) & Datiscaceae & $\begin{array}{l}\text { Hanönü/Göller } \\
\text { located }\end{array}$ & 436 & 78 & $\begin{array}{c}34^{\circ}-27^{\prime}-28,94^{\prime \prime} / 41^{\circ}- \\
37^{\prime}-32,92^{\prime \prime}\end{array}$ \\
\hline $\begin{array}{l}\text { Fire thorn (Pyracantha angustifolia (Franch.) } \\
\text { C.K.Schneid.) }\end{array}$ & Rosaceae & $\begin{array}{l}\text { Bölükyazı/Kadıa } \\
\text { ğa located }\end{array}$ & 975 & 59 & $\begin{array}{l}34^{\circ}-24^{\prime}-35,07^{\prime \prime} / 41^{\circ}- \\
41^{\prime}-30,22^{\prime \prime}\end{array}$ \\
\hline $\begin{array}{l}\text { Horsetail } \\
\text { (Equisetum arvense L.) }\end{array}$ & Equisetaceae & $\begin{array}{l}\text { Hocavakıf/Öküza } \\
\text { ltı located }\end{array}$ & 642 & 83 & $\begin{array}{c}34^{\circ}-22^{\prime}-38,06^{\prime \prime} / 41^{\circ}- \\
41^{\prime}-51,23^{\prime \prime}\end{array}$ \\
\hline $\begin{array}{l}\text { Immortelle (Helichrysum angustifolium (Lam.) } \\
\text { DC.) }\end{array}$ & Asteraceae & $\begin{array}{l}\text { Yukarıçakırçay/ } \\
\text { Yayundurun } \\
\text { located }\end{array}$ & 820 & 89 & $\begin{array}{c}34^{\circ}-34^{\prime}-34,66^{\prime \prime} / 41^{\circ}-40^{\prime}- \\
14,52^{\prime \prime}\end{array}$ \\
\hline $\begin{array}{l}\text { Linden } \\
\text { (Tilia amurensis } \text { Rupr.) }\end{array}$ & Malvaceae & $\begin{array}{l}\text { Kavak/Bürnük } \\
\text { located }\end{array}$ & 958 & 83 & $\begin{array}{l}34^{\circ}-26^{\prime}-50,66^{\prime \prime} / 41^{\circ}-42^{\prime}- \\
25,09^{\prime \prime}\end{array}$ \\
\hline $\begin{array}{l}\text { Lion's Claw } \\
\text { (Allcemilla vulgaris L.) }\end{array}$ & Rosaceae & $\begin{array}{l}\text { Yeniköy/Kiremitl } \\
\text { ik located }\end{array}$ & 1021 & 85 & $\begin{array}{c}34^{\circ}-24^{\prime}-41,35^{\prime \prime} / 41^{\circ}-33^{\prime}- \\
3,02^{\prime \prime}\end{array}$ \\
\hline $\begin{array}{l}\text { Marigold } \\
\text { (Calendula officinalis L.) }\end{array}$ & Asteraceae & $\begin{array}{l}\text { Central villages } \\
\text { of Hanonu }\end{array}$ & $442-501$ & 75 & $\begin{array}{l}34^{\circ}-28^{\prime}-1,81^{\prime \prime} / 4^{\circ}-37^{\prime}- \\
37,16^{\prime \prime}\end{array}$ \\
\hline Meadow triangular (Trifolium pratense L.) & Leguminosae & $\begin{array}{c}\text { Kayabașı/ } \\
\text { Melleșler located }\end{array}$ & 1096 & 84 & $\begin{array}{c}34^{\circ}-18^{\prime}-26,80^{\prime \prime} / 41^{\circ}- \\
42^{\prime}-14,93^{\prime \prime}\end{array}$ \\
\hline $\begin{array}{l}\text { Medicinal chamomile } \\
\text { (Matricaria chamomilla L.) }\end{array}$ & Composita & $\begin{array}{l}\text { Kavak/ Soyuk } \\
\text { located }\end{array}$ & 945 & 86 & $\begin{array}{c}34^{\circ}-27^{\prime}-56,96^{\prime \prime} / 41^{\circ}- \\
41^{\prime}-53,14^{\prime \prime}\end{array}$ \\
\hline $\begin{array}{l}\text { Mint } \\
\text { (Mentha } \times \text { piperita L.) }\end{array}$ & Lamiaceae & $\begin{array}{l}\text { Hanönü/Karayap } \\
\text { rak located }\end{array}$ & 463 & 79 & $\begin{array}{l}34^{\circ}-28^{\prime}-21,09^{\prime \prime} / 41^{\circ}-37^{\prime}- \\
33,00^{\prime \prime}\end{array}$ \\
\hline $\begin{array}{l}\text { Mistletoe } \\
\text { (Viscum album L.) }\end{array}$ & Santalaceae & $\begin{array}{c}\text { Bölükyazı/ } \\
\text { Abazoğlu located }\end{array}$ & 972 & 66 & $\begin{array}{c}34^{\circ}-23^{\prime}-59,88^{\prime \prime} / 41^{\circ}- \\
41^{\prime}-51,56^{\prime \prime}\end{array}$ \\
\hline $\begin{array}{l}\text { Orchis } \\
\text { (Orchis morio L.) }\end{array}$ & Orchidaceae & $\begin{array}{l}\text { Yeniköy/Yörükör } \\
\text { en located }\end{array}$ & 1003 & 81 & $\begin{array}{c}34^{\circ}-24^{\prime}-42,38^{\prime \prime} / 41^{\circ}-32^{\prime}- \\
52,31^{\prime \prime}\end{array}$ \\
\hline $\begin{array}{l}\text { Plantago } \\
\text { (Plantago afra L.) }\end{array}$ & Plantaginaceae & $\begin{array}{l}\text { Aşağıçakırçay } \\
\text { located }\end{array}$ & 912 & 80 & $\begin{array}{c}34^{\circ}-34^{\prime}-51,21^{\prime \prime} / 41^{\circ}-37^{\prime}- \\
50,92^{\prime \prime}\end{array}$ \\
\hline $\begin{array}{l}\text { Prunella plum } \\
\text { (Prunus domestica L.) }\end{array}$ & Rosaceae & $\begin{array}{l}\text { Akçasu/Çevrik } \\
\text { located }\end{array}$ & 479 & 65 & $\begin{array}{c}34^{\circ}-21^{\prime}-42,04^{\prime \prime} / 41^{\circ}- \\
35^{\prime}-53,48^{\prime \prime}\end{array}$ \\
\hline $\begin{array}{l}\text { Rose } \\
(\text { Rosa } \times \text { damascena Herrm. })\end{array}$ & Rosaceae & $\begin{array}{l}\text { Hanönü/Donaşar } \\
\text { located }\end{array}$ & 429 & 78 & $\begin{array}{c}34^{\circ}-27^{\prime}-48,70^{\prime \prime} / 41^{\circ}-37^{\prime}- \\
29,62^{\prime \prime}\end{array}$ \\
\hline $\begin{array}{l}\text { Rosemary } \\
\text { (Rosmarinus eriocalyx Jord. \& Fourr.) }\end{array}$ & Lamiaceae & $\begin{array}{l}\text { Yenice/Köyiçi } \\
\text { located }\end{array}$ & 433 & 81 & $\begin{array}{c}34^{\circ}-32^{\prime}-59,26^{\prime \prime} / 41^{\circ}-36^{\prime}- \\
58,46^{\prime \prime}\end{array}$ \\
\hline Snake pillow (Dracunculus vulgaris Schott) & Araceae & $\begin{array}{l}\text { Halkabük/Göçeb } \\
\text { e located }\end{array}$ & 462 & 84 & $\begin{array}{c}34^{\circ}-30^{\prime}-48,66^{\prime \prime} / 41^{\circ}- \\
37^{\prime}-9,06^{\prime \prime}\end{array}$ \\
\hline St. John'sWort (Hypericum perforatum L.) & Hypericaceae & $\begin{array}{l}\text { Yeniköy/Kiremitl } \\
\text { ik located }\end{array}$ & 1003 & 85 & $\begin{array}{l}34^{\circ}-25^{\prime}-1,29^{\prime \prime} / 41^{\circ}-33^{\prime}- \\
8,36^{\prime \prime}\end{array}$ \\
\hline $\begin{array}{l}\text { Milk Thistle } \\
\text { (Silybum marianum (L.) Gaertn.) }\end{array}$ & Compositae & $\begin{array}{c}\text { Hocavakıf/ } \\
\text { Ayșeoğlu located }\end{array}$ & 645 & 85 & $\begin{array}{c}34^{\circ}-23^{\prime}-13,92^{\prime \prime} / 41^{\circ}-41^{\prime}- \\
16,27^{\prime \prime}\end{array}$ \\
\hline $\begin{array}{l}\text { Thyme } \\
\text { (Thymus plasonii Adamovic) }\end{array}$ & Lamiaceae & $\begin{array}{l}\text { Yukarıçakırçay/ } \\
\text { Yayundurun } \\
\text { located }\end{array}$ & 819 & 89 & $\begin{array}{c}34^{\circ}-34^{\prime}-37,46^{\prime \prime} / 41^{\circ}-40^{\prime}- \\
21,20^{\prime \prime}\end{array}$ \\
\hline $\begin{array}{l}\text { Toothpic kweed } \\
\text { (Amni visnaga } \text { L.) }\end{array}$ & Apiaceae & $\begin{array}{l}\text { Vakıfgeymene/Y } \\
\text { azı located }\end{array}$ & 556 & 81 & $\begin{array}{c}34^{\circ}-25^{\prime}-45,26^{\prime \prime} / 41^{\circ}- \\
37^{\prime}-0,58^{\prime \prime}\end{array}$ \\
\hline
\end{tabular}




\section{Belladonna}

(Atropa belladonna L.)

From the Solanaceae family, the beautician grass was observed on the barren and stony grounds in the research area. These areas are Donaşar Mevkii parts of Hanönü District. the area where it is located is $472 \mathrm{~m}$ from the sea. and $72 \mathrm{~km}$ from the city center. Away.

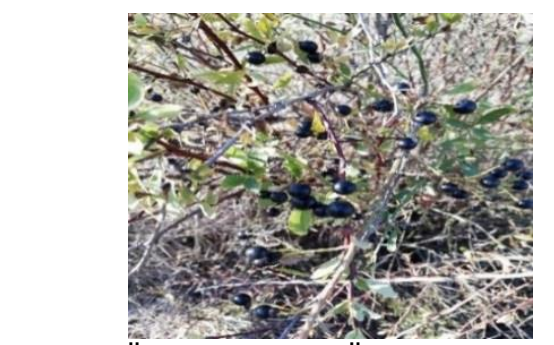

(Murat Özocak/Erkan Ünalan- 13.09.2019)

Figure 4. Atropa belladonna L.

\section{Bitter melon}

(Ecballium elaterium (L.) A.Rich)

It belongs to the Cucurbitaceae family and is known by names such as bitter melons, cirlatan, donkey cucumber. It has been observed that it grows in Yenice Village settlement area and its surroundings in the research area. $85 \mathrm{~km}$ from the city center. The bitter melon which is determined to be located at a distance of $438 \mathrm{~m}$ from the sea. It is located at a height.

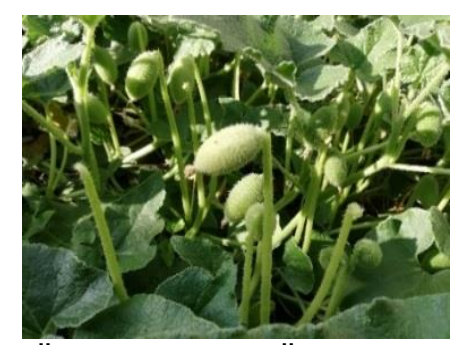

(Murat Özocak/Erkan Ünalan- 21.08.2019)

Figure.5. Ecballium elaterium (L.) A.Rich

\section{Blackthorn}

(Paliurus spina christi Mill.)

Blackthorn, a member of the Rhamnaceae family, is also known as Shrub thorn and barrack thorn. Within the scope of the research, it has been determined that it is present in almost all villages and located in Sinözü District of Kavak village. Sinözü area, where the blackhead is located, is $929 \mathrm{~m}$. and $81 \mathrm{~km}$ from the city center away.

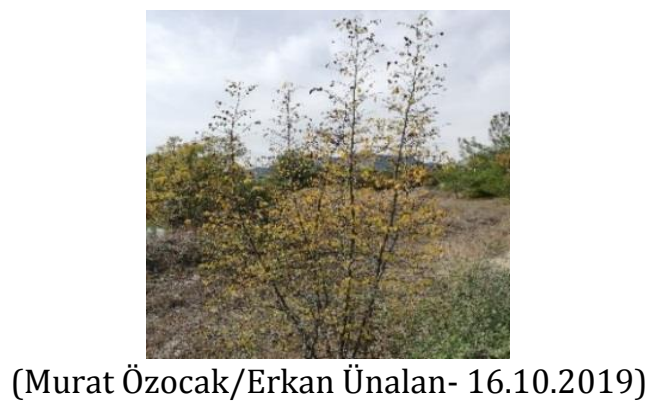

Figure 6. Paliurus spina-christi Mill.

\section{Burdock}

(Arctium lappa subsp. platylepis (Boiss.\& Balansa) Arènes)

Burdock, a family of Asteraceae, has local uses called pitrak. It was determined that it grows naturally in Çay Mahallesi, in the borders of Bölükyazı Village. $972 \mathrm{~m}$ from the sea. Dulavrat grass is located at a height of $61 \mathrm{~km}$ from the city center away.

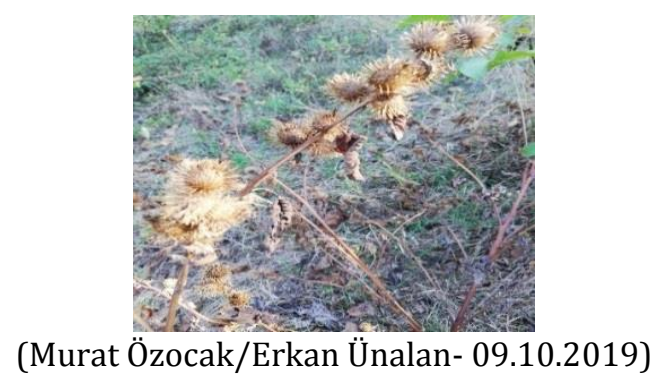

Figure 7. Arctium lappa subsp. platylepis (Boiss. \& Balansa) Arènes

\section{Buttercup}

(Ranunculus ficaria var. bulbifera Albert)

Ranunculaceae family is also known as a buttercup. It has been identified in almost every region in the region and it has been observed that it grows in all villages and gardens of Hanönü district. average $546 \mathrm{~m}$. It has been observed that it grows at altitude levels, $57 \mathrm{~km}$ from the city center. It was determined at a distance. 


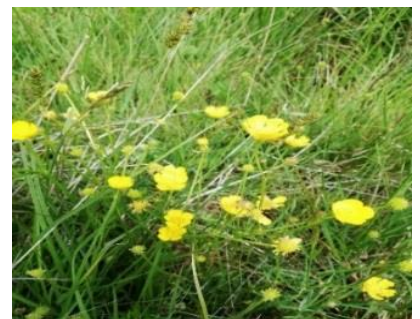

(Murat Özocak/Erkan Ünalan- 23.07.2019)

Figure 8. Ranunculus ficaria var. bulbifera Albert

\section{Caper}

(Capparis spinosa subsp. aegyptia (Lam.) Kit Tan \& Runemark)

Caper, a member of the Capparaceae family, is also referred to as the Gebre in the region. Within the scope of the research, it has been determined that it is present in Kıraç District of Küreçayı Village. $605 \mathrm{~m}$ above sea level. The current location of the capers found at a height is $80 \mathrm{~km}$ from the city center.

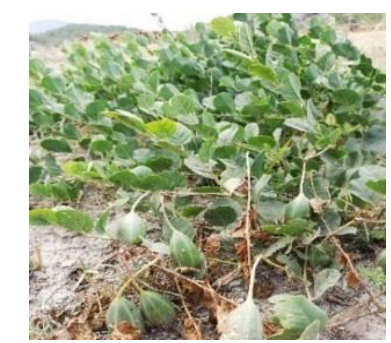

(Murat Özocak/Erkan Ünalan- 24.07.2020)

Figure 9. Capparis spinosa subsp. aegyptia (Lam.) Kit Tan \& Runemark

\section{Charlock}

(Sinapis arvensis L.)

From the Brassicaceae family, it grows frequently in the mustard region, especially in the Yozlu Region within the boundaries of the village of Bölükyazı. The height information determined was $987 \mathrm{~m}$. and the province is $67 \mathrm{~km}$. is for data.

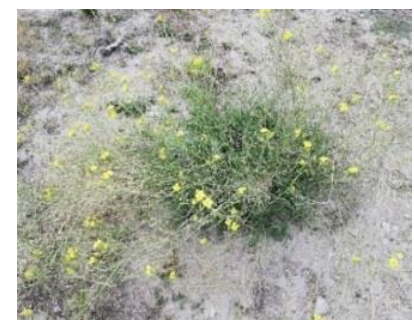

(Murat Özocak/Erkan Ünalan- 11.08.2020)

Figure 10. Sinapis arvensis L.

\section{Dandelion}

(Taraxacum officinale (L.) Weber ex F.H. Wigg.) Dandelion plant, belonging to the Asteraceae family, was found in the Karağaçaltı locality of Gökçeağaç village in the research area.

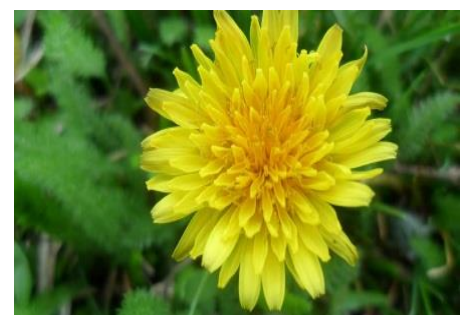

(Murat Özocak/Erkan Ünalan- 19.08.2019)

Figure 11. Taraxacum officinale (L.) Weber ex F.H.Wigg.

Determined area is $448 \mathrm{~m}$. It has a height from the sea and is $76 \mathrm{~km}$ away from the city center.

\section{Dead Nettle}

(Urtica dioica $\mathrm{L}$.)

Dead Nettle, a member of the Urticaceae family, was discovered in the Karaoluk neighborhood of the Hocavakıf Village in the research area. the height of $643 \mathrm{~m}$ from the sea. Urtica dioica L. is $83 \mathrm{~km}$ from the city center.

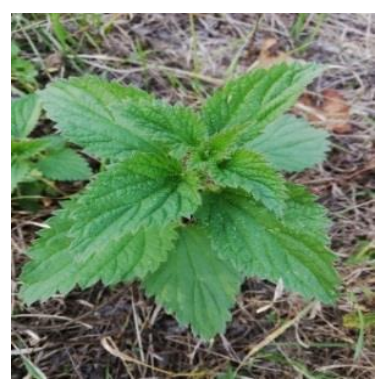

(Murat Özocak/Erkan Ünalan- 29.07.2019)

Figure 12. Urtica dioica L. 


\section{Elderberry}

(Sambucus adnata Wall. ex DC.)

The elderberry, also known as Yivdin, is from the Adoxaceae family. It was determined that it grows in Karayaprak District of Hanönü Merkez District in the research area. $423 \mathrm{~m}$ from the sea and the province is $79 \mathrm{~km}$.

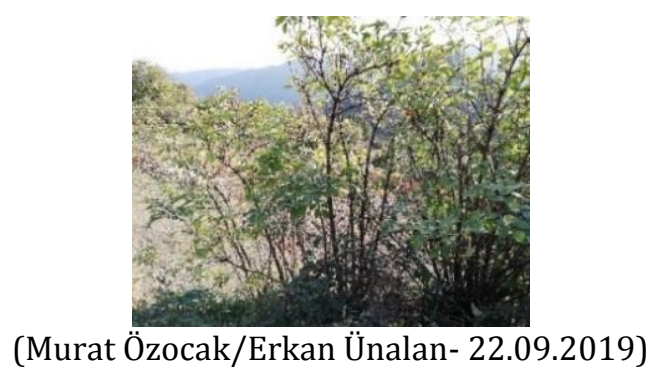

Figure 13. Sambucus adnata Wall. ex DC.

\section{False hemp}

(Cannabina laevis Moench)

It belongs to Datiscaceae family and grows naturally in Gölle Mevkii in Hanönü Central District under false hessian region conditions. False hemp research area $436 \mathrm{~m}$. detected in height. The detected area is 78 $\mathrm{km}$ from the city center.

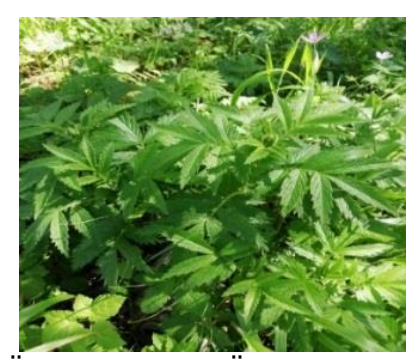

(Murat Özocak/Erkan Ünalan- 26.07.2020)

Figure 14. Cannabina laevis Moench

\section{Fire thorn}

(Pyracantha angustifolia (Franch.)

C.K.Schneid.)

It belongs to the Rosaceae family and is known as the fire thorn or dog apple among the people. It has sweet fruits and can be used for medicinal and aromatic purposes. It was determined that it is located within the boundaries of the village of Bölükyazı in the research area. It is also observed that it is located in the natural environment in the Kadıağa Farm Area. Fire thorn research area $975 \mathrm{~m}$. detected in height. The detected area is $59 \mathrm{~km}$ from the city center.

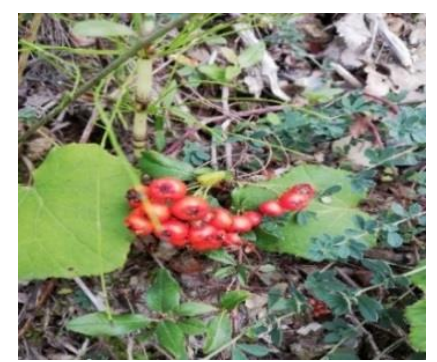

(Murat Özocak/Erkan Ünalan- 25.07.2020)

Figure 15. Pyracantha angustifolia (Franch.) C.K.Schneid.

\section{Horsetail}

(Equisetum arvense L.)

Horsetail plant is belongs to the family Equisetaceae. It was determined that it grows within the boundaries of Öküzaltı District of Hocavakıf Village in the research area. the height of the determined areas from the sea is $642 \mathrm{~m}$. and the distance to the city center was determined as $83 \mathrm{~km}$.

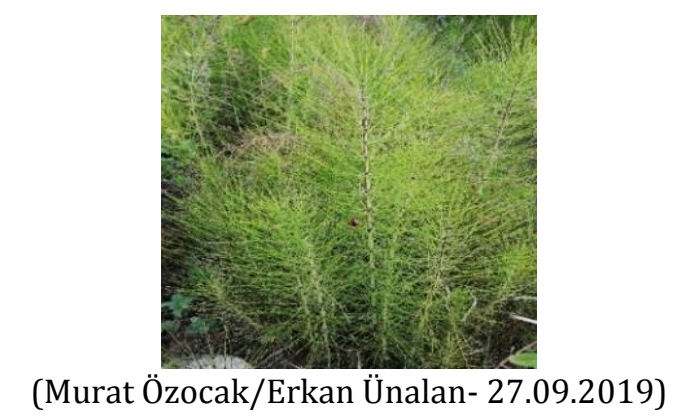

Figure 16. Equisetum arvense L.

\section{Immortelle Herb}

(Helichrysum angustifolium (Lam.) DC.)

The immortal herb from the Asteraceae family is also known as the golden herb. It has been determined that it is present in the Yayundurun Site of Yukaricakircay Village in the research area. Sea height of the designated location is $820 \mathrm{~m}$. It is $89 \mathrm{~km}$ away from the city center. 


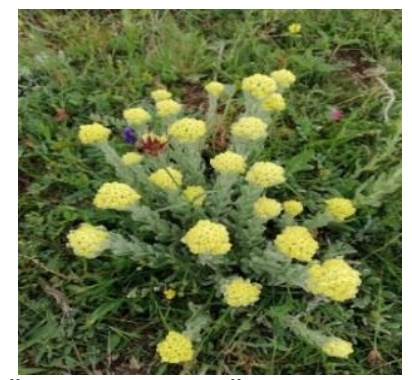

(Murat Özocak/Erkan Ünalan- 10.08.2020)

Figure 17. Helichrysum angustifolium (Lam.) DC.

\section{Linden}

(Tilia amurensis Rupr.)

It is determined that linden tree, which is a family of Malvaceae, is common in Bürnük neighborhood of Kavak Village in the researched region. The altitude of the determined area is $958 \mathrm{~m}$. It is $83 \mathrm{~km}$ away from the city center.

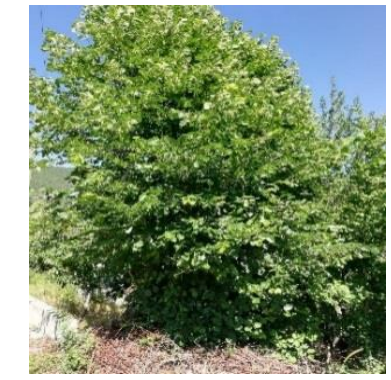

(Murat Özocak/Erkan Ünalan- 12.07.2019)

Figure 18. Linden Tilia amurensis Rupr.

\section{Lion's Claw}

(Allcemilla vulgaris L.)

The lion claw, which belongs to the Rosaceae family, is also known in the region as lion oil, hazelnut and falcon

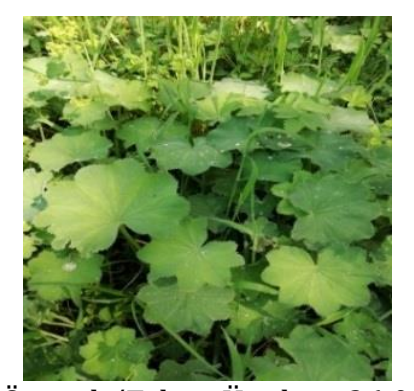

(Murat Özocak/Erkan Ünalan- 26.08.2019)
It has been determined that the lion claw plant grows frequently in the Kiremitlik region of the Yeniköy Village. Lion's claw research area $1021 \mathrm{~m}$. detected in height. The detected area is $85 \mathrm{~km}$ from the city center.

\section{Marigold}

(Calendula officinalis L.)

The calendula plant, also known as nocturnal or orange daffodil, belongs to the Asteraceae family. It grows in the garden of Hanönü District Agriculture and Forestry Directorate. Although its height from the sea varies between $442-501 \mathrm{~m}$, it is $75 \mathrm{~km}$ away from the city center.

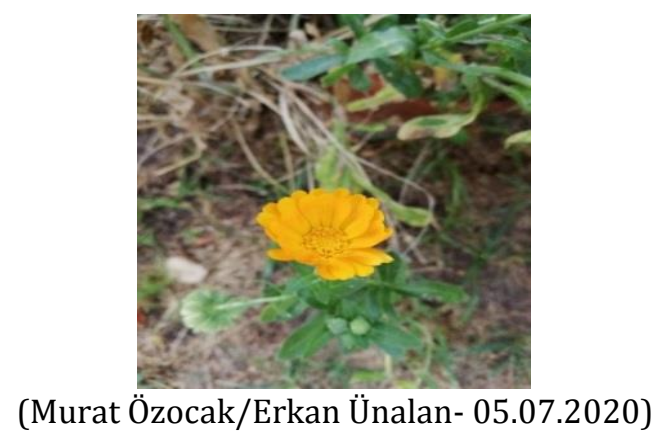

Figure 20. Calendula officinalis L.

\section{Meadow triangular}

(Trifolium pratense L.)

The meadow, which belongs to the Gramineae family, is also known as triple red clover. It has been determined that it is common in the research area of Kayabaşı Village, Melleşler. Meadow triangular research area $1096 \mathrm{~m}$. detected in height. The detected area is $84 \mathrm{~km}$ from the city center.

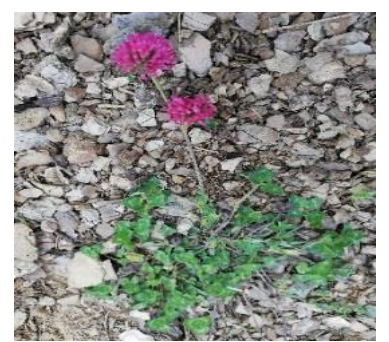

(Murat Özocak/Erkan Ünalan- 19.08.2019)

Figure 19. Allcemilla vulgaris $\mathrm{L}$.

Figure 21. Trifolium pratense $\mathrm{L}$. 


\section{Medicinal Chamomile}

(Matricaria chamomilla L.)

Medicinal chamomile is a family of Asteraceae, also referred to as authentic chamomile.

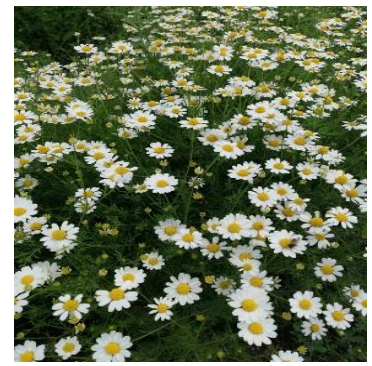

(Murat Özocak/Erkan Ünalan- 20.08.2019)

Figure 22. Matricaria chamomilla L.

Within the scope of the research, it has been determined that it grows in Soyuk District of Kavak Village. Its location is $945 \mathrm{~m}$ from the sea and its distance to the city center is 86 $\mathrm{km}$.

\section{Mint}

(Mentha $\times$ piperita L.)

Mint from the Lamiaceae family is popularly known as mint and garden mint. It is frequently encountered in the research area in the Karayaprak District of the Hanönü Merkez District. Altitude information is 463 $\mathrm{m}$ and its distance to the center is $79 \mathrm{~km}$.

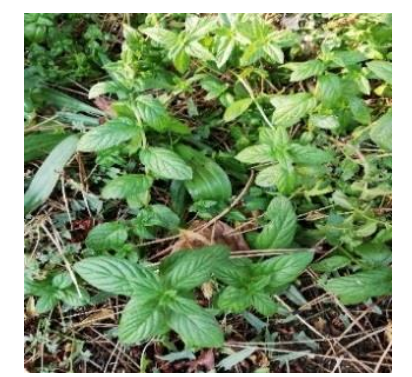

(Murat Özocak/Erkan Ünalan- 09.08.2020)

Figure 23. Mentha $\times$ piperita $\mathrm{L}$.

\section{Mistletoe}

(Viscum album L.)

Mistletoe from the Santalaceae family is also known as moth and moth. It has been determined that it grows in the Abazoğlu
Neighborhood of Baöükyazı Village in the research area.

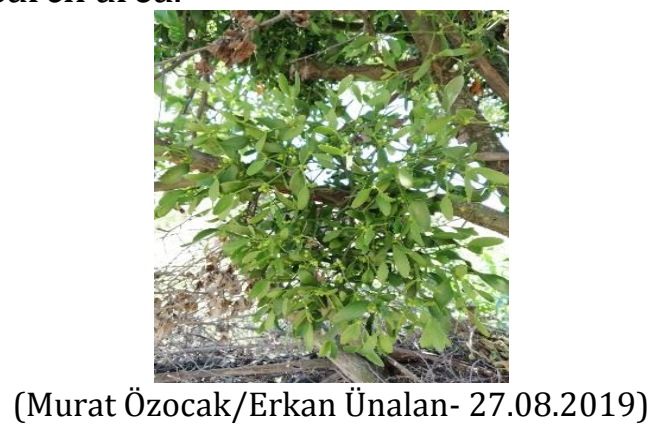

Figure 24. Viscum album L.

\section{Orchis}

(Orchis morio L.)

Orchis, which belongs to Orchidaceae family, grows in the borders of Yuruköy Village, Yurukoy Quarter in the research area. The height from the sea was determined as 1003 m. The distance to the city center was determined as $81 \mathrm{~km}$.

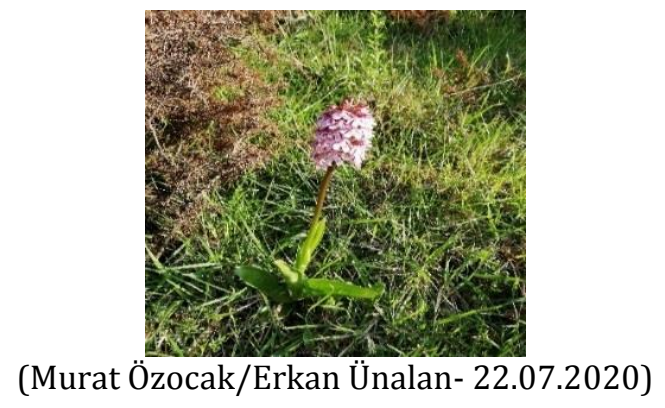

Figure 25. Orchis morio L.

\section{Plantago}

(Plantago afra L.)

Although it is known as plantain or herb grass belonging to the family of Plantaginaceae, it is known as boiled grass, wound grass, vascular grass in the region.

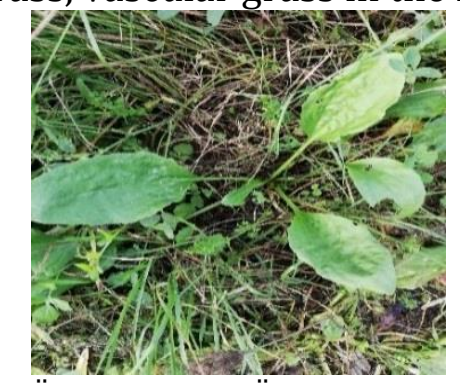

(Murat Özocak/Erkan Ünalan- 22.07.2020)

Figure 26. Plantago afra L. 
It has been found abundantly in the research area of the Lower Çakırçay Village settlement area and its surroundings. Sea height of the designated location is $912 \mathrm{~m}$. It is $80 \mathrm{~km}$ away from the city center.

\section{Prunella Plum}

(Prunus domestica L.)

The plum, which belongs to the Rosaceae family, known as alaik or uryani, is grown especially in the Kastamonu region and its fruit has a positive effect against digestive system disorders. Their location in the research area is in the Çevrik Mevkii region within the borders of Akçasu Village.

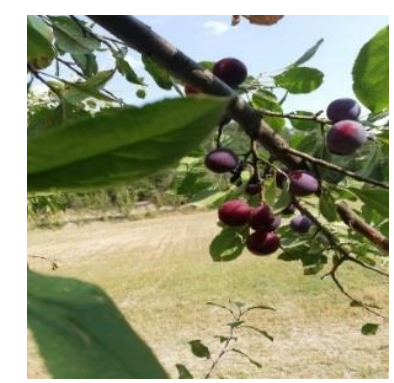

(Murat Özocak/Erkan Ünalan- 28.08.2019)

Figure 27. Prunus domestica L.

\section{Rose}

(Rosa $\times$ damascena Herrm.)

The rose, which belongs to the Rosaceace family, is $429 \mathrm{~m}$ above sea level in the research area. It was determined in height. It is $78 \mathrm{~km}$. grows at a distance. It grows intensely in natural conditions in Hanönü Donaşar location.

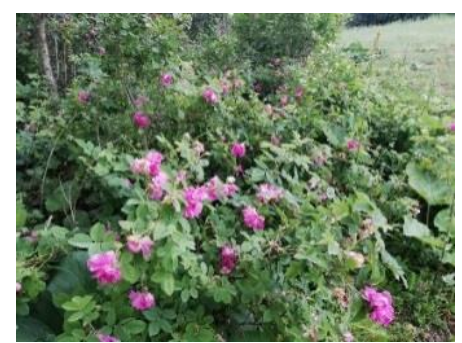

(Murat Özocak/Erkan Ünalan- 10.08.2020)

Figure 28. Rosa $\times$ damascena Herrm.

\section{Rosemary}

(Rosmarinus eriocalyx Jord. \& Fourr.)

Rosemary, also known as bird grass in the region, belongs to the Lamiaceae family. It grows abundantly in the village area of Yenice Village in the research area. The height from the sea was determined as $423 \mathrm{~m}$ and the distance to the city center was determined as $81 \mathrm{~km}$.

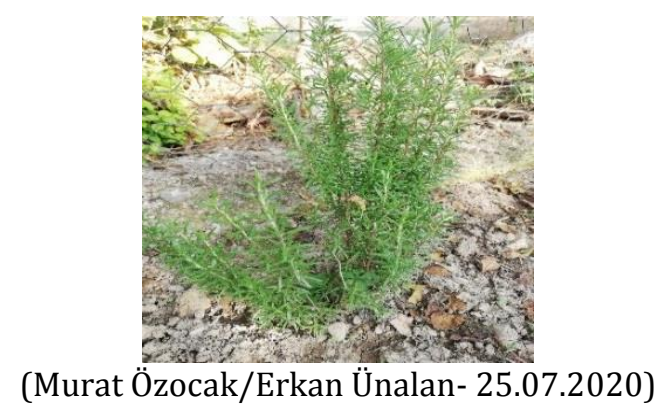

Figure 29. Rosmarinus eriocalyx Jord. \& Fourr.

\section{Snake Pillow}

(Dracunculus vulgaris Schott)

Snake pillow (Beech beet), which belongs to the Araceae family and is known in the region with names such as snake pillow, elephant ear, and shaggy, is known for its good skin psoriasis. It was discovered in the research area around the Göçebe area, within the borders of Halkabük Village.

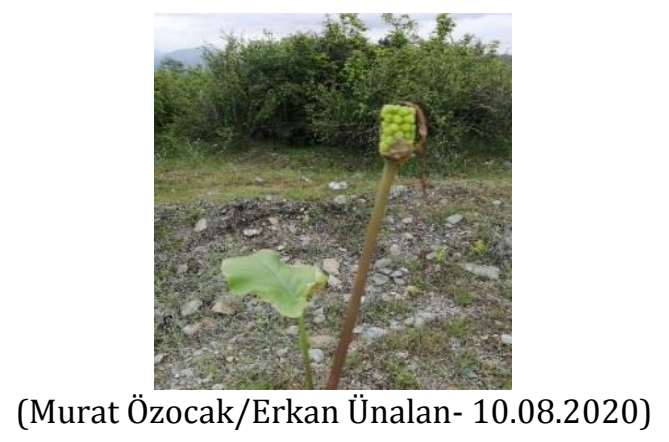

Figure 30. Dracunculus vulgaris Schott

\section{St. John's Wort}

(Hypericum perforatum L.)

St. John's Wort, also known as Hypericaceae family, is also known as sword grass and yeast. In the research area, its groove was 
determined in the Kiremitlik area within the borders of Yeniköy Village. The altitude information is $1003 \mathrm{~m}$ and the distance of the determined region to the city center is determined as $85 \mathrm{~km}$.

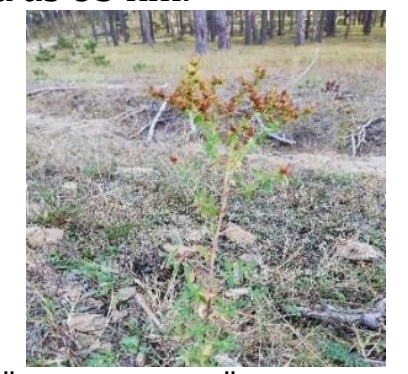

(Murat Özocak/Erkan Ünalan- 21.07.2019)

Figure 31. Hypericum perforatum L.

\section{Milk Thistle}

\section{(Silybum marianum (L.) Gaertn.)}

Thistle, also known as the Virgin Mary's thorn in the region, is a member of the Compositae family. It was discovered at the Ayşeoğlu Site within the boundaries of the Hocavakıf Village in the research area. It is $645 \mathrm{~m}$ high from the sea and it was located at a location $85 \mathrm{~km}$ from the city center.

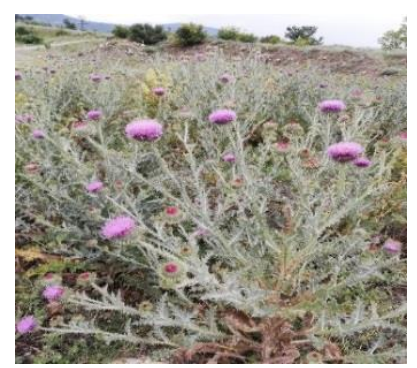

(Murat Özocak/Erkan Ünalan- 12.07.2020)

Figure 32. Silybum marianum (L.)Gaertn.

\section{Thyme}

(Thymus plasonii Adamovic)

Thyme, which belongs to Lamiaceae family, is frequently consumed in the region. It has been observed that it is present at the Yayundurun location within the borders of the Yukari Çakırçay Village in the research area. altitude information $819 \mathrm{~m}$. and the provincial distance was determined as 89 $\mathrm{km}$.

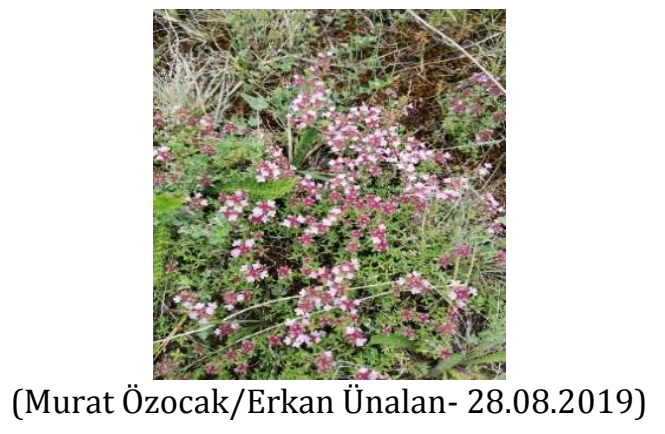

Figure 33. Thymus plasonii Adamovic

\section{Toothpic Kweed}

(Amni visnaga L.)

The apricot of the Apiaceae family is also known as toothpick in the region. It has been determined that there are plenty in the district of Vakıfgeymene Mahallesi Yazi. The height of the determined area from the sea is $556 \mathrm{~m}$ and its distance to the city center is $81 \mathrm{~km}$.

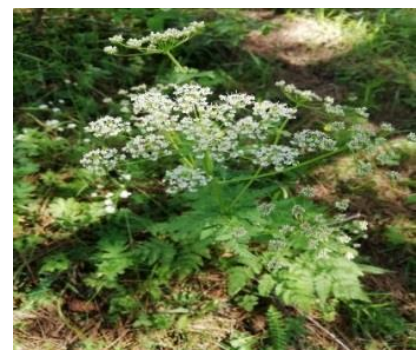

(Murat Özocak/Erkan Ünalan- 09.08.2020)

Figure 34. Amni visnaga L.

\section{Conclusion}

The findings obtained from the research results made in the region of Kastamonu (Hanönü), which includes the natural growing conditions of many plants in terms of vegetation and climate characteristics, are listed below.

As a result of the field studies, 33 medicinal and aromatic plants were identified. People living in the district center and villages, especially those who have been in the region for a long time, know these plants. However, there was no activity in the form of 
collecting from nature or agricultural production.

Although not very much, unconscious removal or damage of these plants has been observed in some regions. There are many medicinal and aromatic plant taxa in the region. A new job opportunity can be easily created by gathering them for commercial purposes or switching to agricultural production. Supporting subjects such as research and $R \& D$ in the region may encourage production and collection. It is possible to establish agricultural structures integrated with the studies related to drying and storage of these plants.

As a result, Kastamonu (Hanönü) region is one of our regions where there are many medicinal and aromatic plants thanks to its suitable climate and vegetation characteristics. Along with these advantages, it has been observed that it is possible to make it better with research and technical activities to be carried out on the subject.

\section{Conflict of Interest}

The authors declare that they have no conflict of interest.

\section{References}

1. Altay, V., Karahan, F., Sarcan, Y.B. \& İlçim, A. 2015a. An ethnobotanical research on wild plants sold in Kirıkhan district (Hatay/Turkey) herbalists and local markets. Biological Diversity and Conservation, 8/2: 81-91.

2. Altay, V., Keskin, M., Karahan, F. (2015b). An assessment of the plant biodiversity of Mustafa Kemal University Tayfur Sokmen campus (Hatay-Turkey) for the view of human health. International Journal of Scientific and Technological Research, 1(2): 83-103

3. Anonymous., 2020. Kastamonu location, Erişim tarihi: 02.03.2020. https://tr.wikipedia.org/wiki/Kastamonu
(il)\#/media/Dosya:Kastamonu districts. png

4. Ceylan, A., 1995. Tıbbi Bitkiler I. E.Ü. Ziraat Fakültesi Yayınları III. Basım No:312. Bornova/İzmir

5. Davis, P.H., 1965. Flora of Turkey and The East Aegean Islands. Edinburgh University Press, Vol. 1., Edinburgh.

6. Davis, P.H., 1967. Flora of Turkey and The East Aegean Islands. Edinburgh University Press, Vol. 2., Edinburgh.

7. Davis, P.H., 1970. Flora of Turkey and The East Aegean Islands. Edinburgh University Press, Vol. 3., Edinburgh.

8. Davis, P.H., 1972. Flora of Turkey and The East Aegean Islands. Edinburgh University Press, Vol. 4., Edinburgh.

9. Davis, P.H., 1975. Flora of Turkey and The East Aegean Islands. Edinburgh University Press, Vol. 5., Edinburgh.

10. Davis, P.H., 1978. Flora of Turkey and The East Aegean Islands. Edinburgh University Press, Vol. 6., Edinburgh.

11. Davis, P.H., 1982. Flora of Turkey and The East Aegean Islands. Edinburgh University Press, Vol. 7., Edinburgh.

12. Davis, P.H., 1984. Flora of Turkey and The East Aegean Islands. Edinburgh University Press, Vol. 8., Edinburgh.

13. Davis, P.H., 1985. Flora of Turkey and The East Aegean Islands. Edinburgh University Press, Vol. 9., Edinburgh.

14. Gürbüz, B., 1999. Çok yıllık tıbbi ve aromatik bitkiler. Türk-Koop. Ekin Dergisi, Yll: 3/7,Ankara, (s:83-87).

15. Güner A, Aslan S, Ekim T, Vural M, Babaç MT (2012) Türkiye Bitkileri Listesi (Damarlı Bitkiler). Nezahat Gökyiğit Botanik Bahçesi ve Flora Araştırmaları Derneği Yayını, Istanbul.

16. Karahan, F., Ozyigit, I. I., Saracoglu, I. A., Yalcin, I. E., Ozyigit, A. H., \& Ilcim, A. (2020). Heavy metal levels and mineral nutrient status in different parts of various medicinal plants collected from eastern Mediterranean region of Turkey. Biological Trace Element Research, 197:316-329. 
17. Kızıl, S., Bayram, E., Kirici, S., Tansi, S., 2010. Tıbbi Ve Aromatik Bitkiler Üretiminin Arttırılması Olanakları. TMMOB, Ziraat Mühendisleri Odası 7. Teknik Kongresi, 11 Ocak 2010, At Ankara, Turkey, Volume: I

18. Ozturk, M., Altay, V., Latıff, A., Salman, T. and Choudhry I. (2018). A Comparative Analysis of the Medicinal Pteridophytes in Turkey, Pakistan, and Malaysia. In Plant and Human Health; Ozturk, M., Hakeem, K. R., Eds.; Springer: Cham, 2018; Vol. 1, pp. 349-390.

19. Öztürk, A., Seki N., Yiğit N., 2017. Ethnobotanical features of some plants used in Taşköprü (Kastamonu/Turkey) region. Biological Diversity and Conservation. 10/3, 136-141.

20. Yaman, K., 2001. Kastamonu İlinde Doğal Olarak Yetișen Başlıca Tıbbi ve Aromatik Bitkilerin Toplama, İşleme ve Pazarlama Maliyetleri ve Söz Konusu Ürünlerin İl Ekonomisine Katkıları. Yüksek Lisans Tezi. Ankara Üniversitesi Fen Bilimleri Enstitüsü Tarım Ekonomisi Anabilim Dalı, Ankara.81pp. 